\title{
WSKAŹNIKOWOŚĆ TWARZY LUDZKIEJ: KRÓTKI PRZEGLĄD PROBLEMATYKI
}

\author{
JOANNA PUPPEL
}

\section{Wstęp}

Esencjonalność człowieka jako gatunku i osoby przejawia się, między innymi, w tym, iż człowiek istnieje w niezwykle istotnym wymiarze 'kultury wizualnej', w której twarz ludzka od niepamiętnych czasów służyła jako główny wskaźnik tzw. wyglądu zewnętrznego oraz różnych stanów emocjonalnych (zob. Bal, 2003). Miała więc od zawsze funkcję niezwykle społeczną i (między)kulturową i to zarówno integrującą jak i dezintegrującą. Fakt ten miał również od zawsze związek z otwartością twarzy i jej uniwersalną (tj. poprzez wszystkie kultury lokalne) dostępnością a także jej estetycznością (zob. np. Strzałko et al., 1996; także Mirzoeff, 1998), co miało i ma istotny związek $z$ funkcjonowaniem człowieka jako przedstawiciela naczelnych w tzw. 'cyklu dziennym' odpowiednio natlenionym i aktywnym percepcyjnie i motorycznie (ang. diurnal cycle, zob. Schmidt i Thews, 1983; także Jurmain et al., 2013). Tak więc człowiek nosił i udostępniał publicznie swoją twarz jako nieodłączny wizerunek $\mathrm{w}$ nieustannej ewolucyjnej sukcesji formacji społecznokulturowo-ekonomicznych, a więc w kulturach myśliwsko-zbierackich, agrarnych jak i w dzisiejszej kulturze miejskiej i wirtualnej (zob. Redican, 1982). W powyższej ewolucyjnej sukcesji twarzy tej, zwłaszcza różnym stanom jej ekspresyjności, przypisywano i przypisuje się określoną semantyczną wskaźnikowość, także związaną z nią określoną wartość komunikacyjno-mediacyjną. Wskaźnikowość definiuje się tutaj jako bezpośrednią korelację czasowo-przestrzenną (a więc typu 'tu i teraz') istniejącą pomiędzy widzialnym określonym układem twarzy a jego znaczeniem.

W niniejszym krótkim opracowaniu omówiona zostanie wskaźnikowość twarzy ludzkiej jako uniwersalnego elementu kultury ludzkiej (zob. np. Brown, 1991) jak 
i najważniejszego w kulturze wizualnej elementu 'komunikacji wskaźnikowej' (ang. indexical comunication, zob. np. Sadowski, 2009). Twarz bowiem w kulturze wizualnej pozostaje jednym z najważniejszych wskaźników komunikacyjnej, ale także i estetycznej, obecności człowieka w otwartej przestrzeni publicznej i w tym wymiarze ma wielkie znaczenie nie tylko dla antropologii, czy w nieco węższym zakresie dla 'antropologii dnia' związanej z cyklem dziennym życia człowieka, dla badań w zakresie historii sztuki, ale także dla komunikologii skupiającej się na badaniu wszelkich przejawów komunikacji międzyludzkiej, w tym różnych form komunikacji niewerbalnej obejmującej także komunikowanie twarzą (zob. Puppel, 2011).

\section{2. 'Naga' twarz i twarz 'uzbrojona'}

W wymienionej powyżej ewolucyjnej sukcesji od kultury myśliwsko-zbierackiej do dzisiejszej kultury miejsko-wirtualnej twarz człowieka zawsze występowała albo jako tzw. 'naga' twarz (ang. naked face) albo jako twarz na różne sposoby 'uzbrojona' w różnego rodzaju ornamenty (ang. ornamented face). W zależności od tego właśnie faktu twarz zawsze reprezentowała różne typy i stopnie (tj. różne nasilenia) semantycznej wskaźnikowości i związanej z nimi siły mediacyjnej w obrębie modalności wzrokowo-dotykowej. Zarówno naga twarz jak i twarz uzbrojona w różne kulturowe artefakty mają swoją siłę interakcyjno-ekspresyjno-performatywną, która jest wykorzystywana przez człowieka mniej lub bardziej świadomie w różnych kontekstach komunikacyjnych. Jest ona także centralną częścią tzw. 'głowy kulturowej' (zob. Puppel, 2015).

\section{2a. Wskaźnikowość nagiej twarzy}

Ten typ wskaźnikowości jest bodaj najlepiej zbadany na gruncie studiów nad komunikacyjnymi zachowaniami człowieka o charakterze niewerbalnym, zwłaszcza w kontekście emocji, które twarze wyrażają. Paul Ekman to badacz szczególnie zasłużony dla komunikologii w badaniach nad twarzą nagą ( $\mathrm{tj}$. nieuzbrojoną w zewnętrzne ornamenty). Zarówno indywidualnie jak i we współpracy z wieloma badaczami poświęcił temu zagadnieniu wiele pionierskich badań i publikacji. Wynika z nich niezbicie, że naga twarz ludzka jest niezwykle czułym uniwersalnym 'urządzeniem' służącym głównie do wyrażania uniwersalnego zestawu emocji (np. strachu, desperacji, bólu, radości, smutku, gniewu, zdziwienia, etc.) i to w kulturach zarówno piśmiennych jak i niepiśmiennych (zob. np. Ekman, 1968; Ekman, 1977; Ekman i Friesen, 1968; Ekman i Friesen, 1969; Ekman i Friesen, 1971; Ekman et al., 1969; Ekman et al., 1972; Ekman i Friesen, 1986; Izard, 1971; Keltner i Ekman, 2000).

Wskaźnikowość nagiej twarzy ludzkiej związana jest z wszelkimi większymi lub mniejszymi czynnościami motorycznymi wykonywanymi przez daną osobę w obrębie twarzy i na jej powierzchni i jednocześnie łatwo zauważalnymi (tj. postrzeganymi) przez inne osoby. Czynności te obejmują takie ruchy jak: 
- utrzymywanie twarzy nieruchomej

- dwustronne lub jednostronne podniesienie brwi

- ściągnięcie brwi

- obustronne rozszerzenie ust w uśmiechu

- jednostronne podniesienie kącika ust

- otwarcie ust

- wygięcie ust ku dołowi

- zaokrąglenie warg

- wysunięcie warg do przodu

- przymknięcie oka lub oczu

- mruganie powiekami

- szerokie otwarcie oczu

- wydęcie policzka lub policzków

- wytworzenie zmarszczek poziomych na czole

- wysunięcie szczęki dolnej wraz z dolną wargą

- cofnięcie szczęki dolnej

- przesunięcie szczęki dolnej w lewo lub w prawo

- ruchy nozdrzami.

Każda z tych czynności wymaga z czysto psycho-fizjologicznego punktu widzenia uprzedniego wykształcenia motoryczności (zob. np. Kail, 2015, zwłaszcza Rozdział 5 odnoszący się do rozwoju motorycznego dziecka) a także odpowiedniego ukształtowania świadomości odnośnie ich semantycznej i percepcyjnej oddzielności jak i świadomości związanej z możliwościami ich zastosowania w interakcji międzyosobowej. Jak więc widać zestaw określonych twarzowych czynności motorycznych pozostający do dyspozycji człowieka jest całkiem spory. Ma to oczywiście związek z wybitną rolą motoryczności twarzowej w komunikacji bezpośredniej typu 'twarzą-w-twarz' (ang. face-to-face), w której komunikowanie wskaźnikowe odgrywa podstawową rolę jako istotnego regulatora dostarczającego odpowiednio skategoryzowanego i wysoce heterogenicznego zestawu bodźców emocjonalnych w przebiegu danego aktu komunikacyjnego (zob. np. Izard, 1993; Brosch et al., 2010). Natomiast zupełnie odrębną kwestią jest ustalenie tzw. 'siły rażenia', zarówno w wymiarze motorycznym jak i percepcyjnym, poszczególnych czynności w komunikowaniu bezpośrednim. Potrzebne są tutaj dalsze badania uzupełniające dotychczas uzyskane wyniki.

\section{2b. Wskaźnikowość twarzy uzbrojonej}

Z kolei tzw. 'twarz uzbrojona', a więc twarz wyposażona w dodatkowe cechy zewnętrzne (wszelaką ornamentację nakładaną na skórę lub zawieszaną na twarzy), takie jak makijaż, tatuaż, kolczyki, pierścienie, ćwieki, paciorki, wisiorki, etc., funkcjonująca jako swoiste i charakterystyczne dla danej kultury lokalnej przedłużenie nagiej twarzy jest odpowiednio mniej przebadana pod kątem przydatności komuni- 
kacyjnej tychże elementów jak i ich roli w procesie komunikacji bezpośredniej. Niemniej badania etnograficzno-antropologiczne dotychczas przeprowadzone w odniesieniu do tzw. kultur pierwotnych (zob. np. klasyczne dzieło Tylora, 1871/2016; Grōning, 1998; Blauer, 1999; również Morris, 2004) nie pozostawiają najmniejszych wątpliwości co do wytworzenia przez gatunek ludzki bardzo szerokiego mechanizmu zawierającego bogaty zestaw środków ornamentacyjnych służących różnym celom, zwłaszcza podkreślaniu zarówno tożsamości zbiorowej i jednostkowej osób je noszących. Można więc mówić tutaj w szerokim kontekście kultury wizualnej o twarzy uzbrojonej jako wyrażającej 'policentryczność kultury wizualnej' (zob. Shohat i Stam, 1998). W szczególności, tak jak to ma miejsce w przypadku nagiej twarzy, twarz uzbrojona służyła zawsze w perspektywie historycznej podkreślaniu takich uniwersalnych stanów jak: agresja, obrona, poświęcenie, żałoba i smutek, melancholia, ekstaza, triumf, bogactwo, potęga i znaczenie, zdrowie, wiek, afiliacja, etc. Szczegółowe omówienie obecności tych cech zewnętrznych twarzy uzbrojonej ma ogromne znaczenie nie tylko dla wizerunkowości poszczególnych kultur lokalnych ale także dla wskazania ich ewentualnego znaczenia dla procesu komunikacji bezpośredniej w kontekście wielokulturowym.

\section{Wnioski: postulaty odnośnie badań nad wskaźnikowością twarzy ludzkiej}

Powyższy skrótowy przegląd zagadnień związanych z szeroko rozumianą wskaźnikowością twarzy ludzkiej pozwala na wyszczególnienie głównych rejonów badawczych. Są to następujące rejony:

1. Kultura wizualna jako płaszczyzna odniesienia dla badań nad wskaźnikowością twarzy ludzkiej, w tym:

- policentryczność kultury wizualnej

2. Heterogeniczność bodźców emocjonalnych wyrażanych za pomocą nagiej twarzy, w tym:

- komunikacja wskaźnikowa

- polisemiotyczność poszczególnych ekspresji twarzowych.

3. Heterogeniczność bodźców kulturowych wyrażanych za pomocą twarzy uzbrojonej, w tym:

- społeczny charakter twarzy uzbrojonej

- (między)kulturowy charakter twarzy uzbrojonej.

\section{Bibliografia}

Bal, M. 2003. "Visual essentialism and the object of visual culture". Journal of Visual Culture 2. 5-32. Blauer, E. 1999. African elegance. New York: Rizzoli. 
Brosch, T., Pourtois, G. i D. Sander. 2010. "The perception and categorization of emotional stimuli: a review". Cognition and Emotion 24. 377-400.

Brown, D.E. 1991. Human universals. Philadelphia, PA: Temple University Press.

Ekman, P. 1968. "Research findings on recognition and display of facial behavior in literate and nonliterate cultures". Proceedings of the $76^{\text {th }}$ Annual Convention of the American Psychological Association 3.727 (Summary).

Ekman, P. 1977. "Facial expression". W zbiorze: Siegman, A. i S. Feldstein. (red.). Nonverbal behavior and communication. Hillsdale, N.J.: Lawrence Erlbaum Associates. 97-116.

Ekman, P. i W.V. Friesen. 1968. "Nonverbal behavior in psychotherapy research". W zbiorze: Shlien, J. (red.). Research in psychotherapy. Vol. 3. Washington, D.C.: American Psychological Association. 179-216.

Ekman, P., E.R. Sorenson i W.V. Friesen. 1969. "Pan-cultural elements in facial displays of emotions". Science 164. 86-88.

Ekman, P. i W.V. Friesen. 1971. "Constants across cultures in the face and emotions". Journal of Personality and Social Psychology 17.2. 124-129.

Ekman, P., W.V. Friesen i P. Ellsworth. 1972. Emotions in the human face: guidelines for research and integration of findings. New York: Pergamon Press.

Ekman, P. i W.V. Friesen. 1986. "A new pan-cultural facial expression of emotion". Motivation and emotion 10.2. 159-168.

Grōning, K. 1998. Body decoration: a world survey of body art. New York: Vendome Press.

Izard, C.E. 1971. The face of emotion. New York: Appleton.

Izard, C.E. 1993. "Four systems for emotion activation: cognitive and noncognitive processes". Psychological Review 100.1. 68-90.

Jurmain, R., Kilgore, L. i W. Trevathan. 2013. Wyd. 9. Essentials of physical anthropology. Wadsworth: Cengage Learning.

Kail, R.V. 2015. Children and their development. Wyd. 7. Toronto: Pearson.

Keltner, D. i P. Ekman. 2000. "Facial expression of emotion". W zbiorze: Lewis, M. i J. Haviland. (red.). Handbook of emotions. Wyd. 2. New York: Guilford Publications. 236-249.

Mirzoeff, N. (red.). 1998. The visual culture reader. London: Routledge.

Morris, D. 2004. The naked woman: a study of the female body. New York: St. Martin's Press.

Puppel, J. 2011. "Uwagi w sprawie zarządzania twarzą w przestrzeni publicznej". W zbiorze: Puppel, S. (red.). Transkomunikacja. Poznań: Katedra Ekokomunikacji UAM. 81-89.

Puppel, J. 2015. "Głowa człowieka jako węzeł kulturowo-komunikacyjny: uwagi w sprawie głowy kulturowej". Scripta Neophilologica Posnaniensia XV. 189-206.

Redican, W.K. 1982. "An evolutionary perspective on human facial displays". W zbiorze: Ekman, P. (red.). Emotion in the human face. Wyd. 2. Cambridge: Cambridge University Press. 212-280.

Rule, N.O., Ambady, N., Adams, R.B., H. Ozono, S. Kakashima, S. Yoshikawa i M. Watabe. 2010. "Polling the face: prediction and consensuses across cultures". Journal of Personality and Social Psychology 98.1. 1-15.

Sadowski, P. 2009. From interaction to symbol: a systems view of the evolution of signs and communication. Amsterdam: John Benjamins.

Schmidt, R.F. i G. Thews. (red.). 1983. Human physiology. Berlin: Springer-Verlag.

Shohat, E. i R. Stam. 1998. "Narrativizing visual culture: towards a polycentric aesthetics". W zbiorze: Mirzoeff, N. (red.). 27-49. 
Strzałko, J., Kaszycka, K. i B. Kujawa. 1996. "Najpiękniejsza jest przeciętna”. Wiedza i Życie 5. 20-22.

Tylor, E.B. 1871/2016. Primitive culture: researches into the development of mythology, philosophy, religion, language, art and custom in two volumes. New York: Dover Publications. 